\title{
REACTIVITY OF PROPYLENE OXIDES TOWARDS DEOXYCYTIDINE AND IDENTIFICATION OF REACTION PRODUCTS
}

\author{
Z. DJURIC and J.E. SINSHEIMER* \\ College of Pharmacy, The University of Michigan, Ann Arbor, MI 48109 (U.S.A.) \\ (Received September 27th, 1982) \\ (Revision received February 27th, 1984) \\ (Accepted March 2nd, 1984)
}

\section{SUMMARY}

Deoxycytidine was reacted with four epoxides of varying alkylating rates: propylene oxide, glycidol, epichlorohydrin and trichloropropylene oxide. Deoxycytidine was chosen to compare the reactivities of these epoxides as all sites of possible alkylation, the oxygen and both nitrogens, are involved in base pairing in DNA. Reaction products were separated on HPLC. Products of the least and most reactive epoxides, propylene oxide and trichloropropylene oxide, were characterized by UV, IR, $360 \mathrm{MHz}$ NMR and MS analysis. For the epichlorohydrin and glycidol reactions and all analytical separations, products were characterized by their HPLC retention times and UV spectra. While differences in reactivity among the epoxides towards specific nitrogen and oxygen sites were found, total reactivity correlated with Taft $\sigma^{*}$-values of the substituent groups.

Key words: Deoxycytidine alkylations - Propylene oxides - Mutagenicity Taft $\sigma^{*}-$ Site of alkylation

\section{INTRODUCTION}

Our research on structure-mutagenicity relationships for aliphatic epoxides [1-2] has prompted us to extend the studies available on interactions of propylene oxides with nucleosides [3-6]. We are interested in further developing methodology for the separation and identification of nucleoside

\footnotetext{
*To whom correspondence should be addressed. layer chromatography.

Abbreviations: B, pyrimidine base; dCyd, deoxycytidine; DMSO, dimethylsulfoxide; EC, epichlorohydrin; GL, glycidol; HPLC, high pressure liquid chromatography; IS, internal standard; M, molecular ion; 3-methyl-dCyd, 3-methyldeoxycytidine; PO, propylene oxide; R, alkyl side chain; $\mathrm{S}$, deoxysugar; TCPO, trichloropropylene oxide; TLC, thin- 
adducts with propylene oxides as a step towards elucidating their reactivity with DNA and understanding their mechanism of mutagenesis. In this study, deoxycytidine (dCyd) was selected for investigation since it has been indicated to have a wide range of reactivity among the propylene oxides of interest [6] and because it represents a nucleoside for which all sites of possible alkylation on the heterocycle, the $\mathrm{N}-3, \mathrm{~N}^{4}$ and $\mathrm{O}^{2}$, are involved in base pairing in DNA. It was the purpose of this investigation to identify alkylation products of dCyd with propylene oxide (PO) and trichloropropylene oxide (TCPO) by IR, NMR and MS spectra as well as by UV spectra to confirm that UV spectra can be used to determine the site of alkylation. The extent of alkylation by PO and TCPO was then compared with that of epichlorohydrin (EC) and glycidol (GL). Alkylation of dCyd by these four epoxides was correlated to Taft $\sigma^{*}$-values [7] for the substituents, $\mathrm{X}=\mathrm{CH}_{3}, \mathrm{CH}_{2} \mathrm{OH}$, $\mathrm{CH}_{2} \mathrm{Cl}$ and $\mathrm{CCl}_{3}$, on

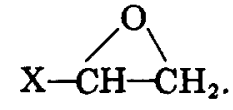

\section{MATERIALS AND METHODS}

\section{Chemicals}

The propylene oxides were purchased from Aldrich Chemical Co. (Milwaukee, WI) and dCyd, as well as 3-methyldeoxycytidine (3-methyl-dCyd) were purchased from Sigma Chemical Co. (St. Louis, MO). For ${ }^{1} \mathrm{H}-\mathrm{NMR}$, $100.00 \%$ gold label $\mathrm{D}_{2} \mathrm{O}$ or $99.9 \%$ gold label DMSO- $d_{6}$ were purchased from Aldrich Chemical Co. Infrared quality potassium bromide was from Harshaw (Solon, $\mathrm{OH}$ ).

\section{Reactions}

Preparative reactions were carried out with approx. $10 \mathrm{mg} \mathrm{dCyd}$, accurately weighed, for each reaction to which $225 \mu$ l buffer $(50 \mathrm{mM}$ Tris $-\mathrm{HCl}$, pH 7.4) and $25 \mu \mathrm{l}$ of PO or TCPO were added per mg of dCyd. Reaction vials were placed in a shaking water bath at $37^{\circ} \mathrm{C}$ for $48 \mathrm{~h}$. Comparative reactions with all four epoxides were also conducted with approx. $10 \mathrm{mg}$ dCyd but the dCyd was dissolved in a solution of epoxide in $60 \%$ methanol $/ 40 \% 0.1 \mathrm{M}$ ammonium formate ( $\mathrm{pH} \mathrm{7.4)} \mathrm{buffer.} \mathrm{For} \mathrm{every} 1 \mathrm{mg}$ of dCyd, $250 \mu \mathrm{l}$ of buffer solution containing $300 \mu \mathrm{mol}$ of epoxide was added. Reaction vials were placed in the shaking water bath at $37^{\circ} \mathrm{C}$ for $24 \mathrm{~h}$.

\section{Chromatography}

Thin-layer chromatography (TLC) on prescored $2 \times 10 \mathrm{~cm} 250 \mu$ silica GF uniplates (Analtech, Newark, DE) was used to monitor reactions. Solvent systems used were: (A) $n$-butanol/ethanol/water $(80: 10: 25)$, (B) isopropanol/ammonia/water $(70: 10: 20)$ and (C) $n$-butanol/acetone/acetic acid/ water $(10: 10: 2: 5)$.

Analytical high pressure liquid chromatography (HPLC) on an Altex system (Berkeley, CA) with UV detection at $254 \mathrm{~nm}$ was carried out using a strong cation exchange column, Partisil SCX $(4.6 \mathrm{~mm} \times 25 \mathrm{~cm})$ from Whatman (Clifton, NJ). The mobile phase was $0.1 \mathrm{M}$ ammonium formate buffer 
adjusted to $\mathrm{pH} 3.5$ with formic acid. A flow rate gradient of $1.7 \mathrm{ml} / \mathrm{min}$ to $2.2 \mathrm{ml} / \mathrm{min}$ over $12 \mathrm{~min}$ was used and at $8 \mathrm{~min}$ the chart speed was decreased from 30 to $15 \mathrm{~cm} / \mathrm{min}$. Reaction solutions were diluted 1:5 with mobile phase buffer containing $0.02 \%$ pyridine as an internal standard and 20- $\mu \mathrm{l}$ aliquots were injected onto the column. All products are referred to as labelled in the Fig. 1 chromatograms.

For the PO and TCPO reactions, semi-preparative cation exchange HPLC was performed with a Whatman Partisil SCX Magnum $9(10 \mathrm{~mm} \times 50 \mathrm{~cm})$ column using $0.08 \mathrm{M}$ ammonium formate buffer $(\mathrm{pH} 3.5$ ) at $3 \mathrm{ml} / \mathrm{min}$. Corresponding product fractions were pooled from five, $0.35-\mathrm{ml}$ injections of undiluted reaction mixture. The pooled fractions were freeze dried, redissolved in a small amount of water, and then purified using a Whatman Partisil ODS Magnum 9 column with a methanol/water gradient of 5-100\% methanol over $25 \mathrm{~min}$ at a flow rate of $1.5 \mathrm{ml} / \mathrm{min}$. Traces of buffer and unreacted material eluted within 25 min while products eluted at about 30 min. For IR analysis, approx. $20 \%$ of each product fraction from the reverse phase separation was mixed with $30 \mathrm{mg}$ of $\mathrm{KBr}$ and freeze dried. The remaining product fraction was freeze dried directly and then used for MS and NMR analyses.

\section{UV spectra}

UV spectra were taken on a Hewlett Packard (Palo Alto, CA) Model $8450 \mathrm{~A} \mathrm{UV/VIS} \mathrm{spectrophotometer.} \mathrm{UV} \mathrm{spectra} \mathrm{of} \mathrm{products} \mathrm{collected} \mathrm{pre-}$ paratively were measured at different $\mathrm{pH}$-values by dilution with high purity water, $0.1 \mathrm{M}$ citrate ( $\mathrm{pH}$ ) buffer, $0.1 \mathrm{M}$ carbonate ( $\mathrm{pH} 9$ ) buffer, $0.1 \mathrm{M} \mathrm{HCl}$ or $0.1 \mathrm{M} \mathrm{NaOH}$. For stability studies, spectra of those samples in $\mathrm{HCl}$ and $\mathrm{NaOH}$ were retaken after standing $24 \mathrm{~h}$ at room temperature. Spectra were also recorded for the latter samples after neutralization of the solutions. Samples collected from the analytical column were dilute and their UV spectra were obtained in the HPLC mobile phase as collected from the column. For all spectra, ratios of the absorbances at $254-280 \mathrm{~nm}$ were calculated.

\section{$I R$ spectra}

IR spectra were obtained on a Perkin-Elmer (Norwalk, CN) Model 281 spectrometer equipped with a model 3600 Data Station. Freeze dried $\mathrm{KBr}$ samples were further dried under vacuum in a drying tube for $5 \mathrm{~h}$ at room temperature and then pressed in paper micro frames $(2 \times 10 \mathrm{~mm}$ aperture). Spectra of the isolated products as indicated were obtained by averaging 20 or 100 scans, as required to obtain satisfactory signal to noise ratios. The absorbance bands for the starting material (dCyd), 3-methyl-dCyd and the isolated products labelled as in Fig. 1 follow: dCyd, $3500-3100 \mathrm{~cm}^{-1}$ strong (s); 2941 shoulder (sh); $1667 \mathrm{~s} ; 1613 \mathrm{~s} ; 1470$ medium (m); 1408 weak (w); 2369 w; 1299 s; 1219 m; 1099 s; 1053 s; 943 w; 901 w; 870 w; 794 s; 720 s. 3-methyl dCyd $3540-3140$ s; $2950 \mathrm{sh} ; 1709$ s; 1682 s; 1651 s; $1556 \mathrm{~s}$; $1431 \mathrm{w} ; 1352 \mathrm{w} ; 1334 \mathrm{w} ; 1296 \mathrm{~m} ; 1250 \mathrm{~s} ; 1212 \mathrm{~s} ; 1170 \mathrm{w} ; 1119-1096 \mathrm{~s}$; $1057 \mathrm{~s} ; 989 \mathrm{~s} ; 816 \mathrm{w} ; 761 \mathrm{~s} ; 666 \mathrm{w}$. PO-1 (20 scans averaged) $3500-3400 \mathrm{~s}$; 

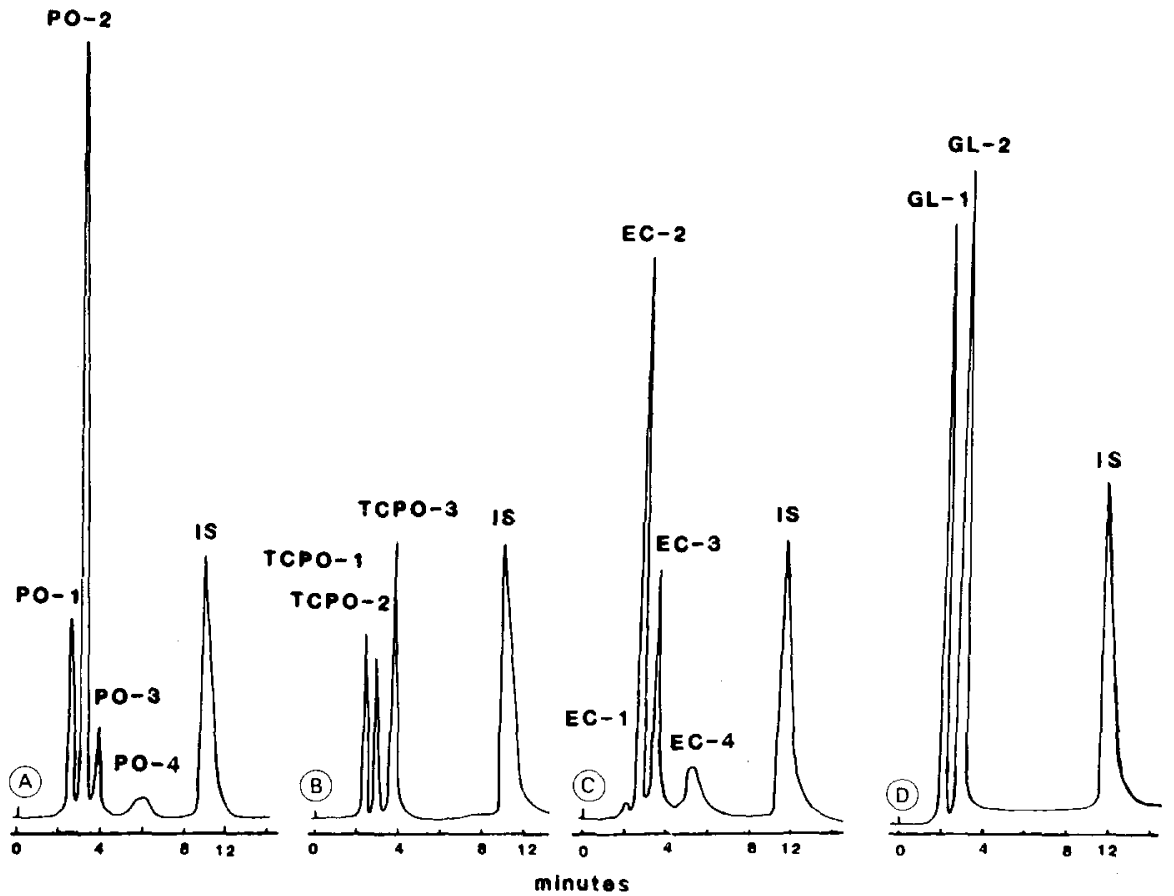

Fig. 1. Analytical cation exchange HPLC chromatograms of 24-h reactions: (A) deoxycytidine with propylene oxide; (B) deoxycytidine with trichloropropylene oxide; (C) deoxycytidine with epichlorohydrin; (D) deoxycytidine with glycidol.

2960-2950 sh; $1710 \mathrm{sh} ; 1660 \mathrm{~s} ; 1630 \mathrm{~s} ; 1450 \mathrm{w} ; 1380 \mathrm{w} ; 1269 \mathrm{~m} ; 1210 \mathrm{w}$; $1090-1050 \mathrm{~s} ; 990 \mathrm{sh} ; 940 \mathrm{w} ; 910 \mathrm{w} ; 835 \mathrm{sh} ; 800 \mathrm{~m} ; 762 \mathrm{~m} ; 710 \mathrm{w} ;$ TCPO-1 (100 scans averaged) $3520-3150 \mathrm{~s} ; 2912 \mathrm{sh} ; 1708 \mathrm{sh} ; 1663 \mathrm{~s} ; 1647 \mathrm{~s}$; $1463 \mathrm{~m} ; 1403 \mathrm{~m} ; 1271 \mathrm{~m} ; 1251 \mathrm{w} ; 1094-1050 \mathrm{~s} ; 876 \mathrm{~m} ; 801 \mathrm{~s} ; 620 \mathrm{~m}$. TCPO-3 (100 scans averaged) $3339-3100 \mathrm{~s} ; 2930 \mathrm{sh} ; 1726 \mathrm{sh} ; 1665 \mathrm{~s}$; $1593 \mathrm{~s} ; 1533 \mathrm{w} ; 1468 \mathrm{w} ; 1404 \mathrm{w} ; 1356 \mathrm{w} ; 1280 \mathrm{~m} ; 1098 \mathrm{w} ; 917 \mathrm{w} ; 877 \mathrm{w}$; $801 \mathrm{~s} ; 761 \mathrm{sh} ; 656 \mathrm{~m} ; 606 \mathrm{~m}$.

\section{NMR spectra}

Proton NMR spectra were taken on a Bruker $360 \mathrm{MHz}$ Fourier Transform spectrometer. Samples of 1-2 mg were dissolved in $99.9 \%$ DMSO- $d_{6}$. The shifts in ppm from tetramethylsilane, including the effect of decoupling and $\mathrm{D}_{2} \mathrm{O}$ exchange, are listed.

TCPO-3, DMSO-d 6 : $\delta 7.50(\mathrm{~d}, \mathrm{~J}=8.4 \mathrm{~Hz}, 1,6-\mathrm{H}), 6.86($ broad, $1, \mathrm{NH}), 6.18$ $\left(\mathrm{t}, \mathrm{J}=6.9,1,1^{\prime}-\mathrm{H}\right), 5.97(\mathrm{~d}, \mathrm{~J}=8.4,1,5-\mathrm{H}), 6.66(\mathrm{t}, \mathrm{J}=6.5,1, \mathrm{COH}), 5.24(\mathrm{~d}$, $\left.\mathrm{J}=4.1,1,3^{\prime}-\mathrm{OH}\right), 4.98\left(\mathrm{t}, \mathrm{J}=5.5,1,5^{\prime}-\mathrm{OH}\right), 4.21$ (q, J=3.0, 1, $\left.3^{\prime}-\mathrm{H}\right), 4.15$ (m, 1, CH), 3.75 (m, 1, 4'-H), $3.53\left(\mathrm{~m}, 2,5^{\prime}-\mathrm{H}\right), 3.4(\mathrm{~m}$, overlap with HDO $\left.\mathrm{CH}_{2}\right), 2.05\left(\mathrm{~m}, 2,2^{\prime}-\mathrm{H}\right)$; decouple at 4.15: $6.65(\mathrm{~d}, \mathrm{~J}=10,1, \mathrm{COH})$ and simplified the multiplet at 3.4; decouple at 2.05: $4.21\left(\mathrm{~s}, 1,3^{\prime}-\mathrm{H}\right), 6.18(\mathrm{~s}, 1$, $\left.1^{\prime}-\mathrm{H}\right) ; \mathrm{D}_{2} \mathrm{O}$ exchange: $7.47(\mathrm{~d}, \mathrm{~J}=7.9,1,6-\mathrm{H}), 6.16\left(\mathrm{t}, \mathrm{J}=6.8,1,1^{\prime}-\mathrm{H}\right), 5.96$ $(\mathrm{d}, \mathrm{J}=8.3,1,5-\mathrm{H}), 4.30$ (q, J=3.4, 1, $\left.3^{\prime}-\mathrm{H}\right), 4.14(\mathrm{t}, \mathrm{J}=8.5,1, \mathrm{CH}), 3.75$ (q, 
$\left.\mathrm{J}=3.4,1,4^{\prime}-\mathrm{H}\right), 3.52\left(\mathrm{~m}, 2,5^{\prime}-\mathrm{H}\right), 3.23-3.43\left(\mathrm{~m}, 2, \mathrm{CH}_{2}\right), 2.04\left(\mathrm{~m}, 2,2^{\prime}-\mathrm{H}\right)$; decouple at 3.43-3.33: simplified the multiplet at 4.14.

TCPO-1, DMSO-d 6 : 7.91 (d, J=8.0, 1, 6-H), $7.5($ broad, 1, NH), $6.81(\mathrm{t}$, $\mathrm{J}=5.1,1, \mathrm{COH}), 6.18\left(\mathrm{t}, \mathrm{J}=6.0,1,1^{\prime}-\mathrm{H}\right), 5.80(\mathrm{~d}, \mathrm{~J}=8.2,1,5-\mathrm{H}), 5.26(\mathrm{~d}$, $\left.\mathrm{J}=4.2,1,3^{\prime}-\mathrm{OH}\right), 5.04\left(\mathrm{t}, \mathrm{J}=4.9,1,5^{\prime}-\mathrm{H}\right), 4.44\left(\mathrm{~m}, 2, \mathrm{CH}_{2}\right), 4.24(\mathrm{~m}, 1$, $\left.3^{\prime}-\mathrm{H}\right), 4.03(\mathrm{~m}, 1, \mathrm{CH}), 3.80\left(\mathrm{~m}, 1,4^{\prime}-\mathrm{H}\right), 3.57\left(\mathrm{~m}, 2,5^{\prime}-\mathrm{H}\right), 2.10 \mathrm{im}, 2$, $\left.2^{\prime}-\mathrm{H}\right), \mathrm{D}_{2} \mathrm{O}$ exchange: $7.90(\mathrm{~d}, \mathrm{~J}=8.0,1,6-\mathrm{H}), 6.16\left(\mathrm{t}, \mathrm{J}=5.8,1,1^{\prime}-\mathrm{H}\right), 5.75$ $(\mathrm{d}, \mathrm{J}=8.0,1,5-\mathrm{H}), 4.42\left(\mathrm{~m}, 2, \mathrm{CH}_{2}\right), 4.22\left(\mathrm{q}, \mathrm{J}=2.6,1,3^{\prime} \cdot \mathrm{H}\right), 4.02(\mathrm{t}, \mathrm{J}=9.4$, $1, \mathrm{CH}), 3.80\left(\mathrm{q}, \mathrm{J}=3.8,1,4^{\prime}-\mathrm{H}\right), 3.5\left(\mathrm{~m}\right.$, overlap with $\left.\mathrm{HDO}, 5^{\prime}-\mathrm{H}\right), 2.13(\mathrm{~m}$, $\left.2,2^{\prime}-\mathrm{H}\right)$; decouple at $4.02: 4.44\left(\mathrm{~d}, \mathrm{~J}=7.5,2, \mathrm{CH}_{2}\right)$; decouple at 2.12: 6.18 (s, 1, 1'-H), $4.24\left(\mathrm{~s}, 1,3^{\prime}-\mathrm{H}\right)$.

PO-1, DMSO-d $d_{6}: 7.88$ (d, J=8.2, 1, 6-H), 6.16 (t, J=6.6, 1, 1'-H. 5.73 $(\mathrm{d}, \mathrm{J}=8.1,1,5-\mathrm{H}), \sim 5$ (broad, $\left.4, \mathrm{NH}+3^{\prime}-\mathrm{OH}+5^{\prime}-\mathrm{OH}+\mathrm{COH}\right), 4.22(\mathrm{~m}, 1$, $\left.3^{\prime}-\mathrm{H}\right), 3.87(\mathrm{~m}, 1, \mathrm{CH}), 3.79\left(\mathrm{q}, \mathrm{J}=3.2,1,4^{\prime}-\mathrm{H}\right), 3.61\left(\mathrm{~m}, 2, \mathrm{CH}_{2}\right), 3.56(\mathrm{~m}$, $\left.2,5^{\prime}-\mathrm{H}\right), 2.10\left(\mathrm{~m}, 2,2^{\prime}-\mathrm{H}\right), 1.00\left(\mathrm{~d}, \mathrm{~J}=5.9,3, \mathrm{CH}_{3}\right) ; \mathrm{D}_{2} \mathrm{O}$ exchange: $7.84(\mathrm{~d}$, $\mathrm{J}=8.1,1,6-\mathrm{H}), 6.13\left(\mathrm{t}, \mathrm{J}=6.5,1,1^{\prime}-\mathrm{H}\right), 5.72(\mathrm{~d}, \mathrm{~J}=8.1,1,5-\mathrm{H}), 4.20(\mathrm{~m}, 1$, $\left.3^{\prime}-\mathrm{H}\right), 3.85(\mathrm{~m}, 1, \mathrm{CH}), 3.78\left(\mathrm{q}, \mathrm{J}=3.7,1,4^{\prime}-\mathrm{H}\right), 3.60\left(\mathrm{~m}, 2, \mathrm{CH}_{2}\right), 3.54(\mathrm{t}$, $\left.\mathrm{J}=4.8,2,5^{\prime}-\mathrm{H}\right), 2.07\left(\mathrm{~m}, 2,2^{\prime}-\mathrm{H}\right), 0.99\left(\mathrm{~d}, \mathrm{~J}=5.7,3, \mathrm{CH}_{3}\right)$; decouple at 0.99: simplified the multiplet at 3.85; decouple at 3.78: $4.20\left(t, J=3.7,1,3^{\prime}-H\right)$, $3.54\left(\mathrm{~d}, \mathrm{~J}=5.5,2,5^{\prime}-\mathrm{H}\right)$; decouple at 3.85: simplified the multiplet at 3.60 .

PO-2, DMSO-d 6 : 8.5 (broad, 2, $\mathrm{NH}_{2}$ ), 7.82 (d, J=7.4, 1, 6- H), 6.15 (t, $\left.\mathrm{J}=6.8,1,1^{\prime}-\mathrm{H}\right), 5.75(\mathrm{~d}, \mathrm{~J}=7.5,1,5-\mathrm{H}), 4.21\left(\mathrm{~m}, 1,3^{\prime}-\mathrm{H}\right), 3.76(\mathrm{q}, \mathrm{J}=3.3$, $\left.1,4^{\prime}-\mathrm{H}\right), 3.55\left(\mathrm{~m}, 2,5^{\prime}-\mathrm{H}\right), 1.94\left(\mathrm{~m}, 2,2^{\prime}-\mathrm{H}\right)$; in $\mathrm{D}_{2} \mathrm{O} 7.87(\mathrm{~d}, \mathrm{~J}=7.6,1$, $6-\mathrm{H}), 6.25\left(\mathrm{t}, \mathrm{J}=7.2,1,1^{\prime} \cdot \mathrm{H}\right), 6.08(\mathrm{~d}, \mathrm{~J}=6.1,1,5-\mathrm{H}), 4.42(\mathrm{q}, \mathrm{J}=3.6,1$, $\left.3^{\prime}-\mathrm{H}\right), 4.05\left(\mathrm{q}, \mathrm{J}=3.9,1,4^{\prime}-\mathrm{H}\right), 3.83\left(\mathrm{~m}, 1,5^{\prime}-\mathrm{H}\right), 3.74\left(\mathrm{~m}, 1,5^{\prime}-\mathrm{H}\right), 2.43(\mathrm{~m}$, $\left.1,2^{\prime}-\mathrm{H}\right), 2.30\left(\mathrm{~m}, 1,2^{\prime}-\mathrm{H}\right)$.

3-Methyl-dCyd, DMSO-d : $_{6} 7.43(\mathrm{~d}, \mathrm{~J}=8.0,1,6-\mathrm{H}), 6.18(\mathrm{~s}, 1, \mathrm{NH}), 6.15$ $\left(\mathrm{t}, \mathrm{J}=6.6,1,1^{\prime}-\mathrm{H}\right), 5.88(\mathrm{~d}, \mathrm{~J}=8.2,1,5-\mathrm{H}), 4.21\left(\mathrm{~m}, 1,3^{\prime}-\mathrm{H}\right), 3.76(\mathrm{q}, \mathrm{J}=3.1$, $\left.1,4^{\prime}-\mathrm{H}\right), 3.54\left(\mathrm{~m}, 2,5^{\prime}-\mathrm{H}\right), 2.22\left(\mathrm{~m}, 2,2^{\prime}-\mathrm{H}\right)$.

\section{Mass spectra}

Electron ionization mass spectra were obtained on a Finnigan Model 4023 $\mathrm{GC} / \mathrm{MS}$ instrument at $70 \mathrm{eV}$. Freeze dried samples were introduced by direct probe. Only $m / e$-values greater than 99 and above $1 \%$ relative intensity are listed except as noted. $M / e$ (relative intensity):

TCPO-3, background subtracted, 265 (1.0), 236 (2.3) B-Cl, 155 (4.6) $\mathrm{BH}_{2}-\mathrm{CCl}_{3}, 152$ (1.6), 126 (2.0) 125 (6.6) $\mathrm{BH}_{2}-\mathrm{CCl}_{3} \mathrm{CHO}, 119$ (1.1), 118 (9.6), 117 (98) S, 113 (1.5) $\mathrm{BH}_{2}-\mathrm{R}, 110$ (1.7), 99 (16) S-18.

TCPO-1, background subtracted, 238 (3.1), 237 (1.7), 236 (1.3) B-Cl, 201 (1.1), 155 (7.2) $\mathrm{BH}_{2}-\mathrm{CCl}_{3}, 151$ (1.3), 148 (1.2), 147 (1.4), 146 (11), 137 (2.0), 131 (2.4), 126 (2.8) $\mathrm{BH}_{2}-\mathrm{CCl}_{3} \mathrm{CHO}, 125$ (7.5) BH-CCl ${ }_{3} \mathrm{CHO}, 120(1.9)$, 119 (7.9), 118 (12), 17 (100)S, 113 (3.9) $\mathrm{BH}_{2}-\mathrm{R}, 108$ (1.3), 103 (1.4), 99 (20)S-18.

PO-1, 242 (0.5) M-CH $\mathrm{CH}_{3} \mathrm{CO} 229$ (1.4) $\mathrm{MH}_{2}-\mathrm{R}, 212$ (0.25) $\mathrm{MH}_{2}$-OR 197 (1.3) $\mathrm{B}+28,193(0.3), 179(2.4), 171(4.5), 170(0.4) \mathrm{B}+2,169(0.3) \mathrm{B}+1$, 
155 (3) $\mathrm{BH}_{2}-\mathrm{CH}_{3}, 154$ (1.9), 153 (8.1) $\mathrm{BH}_{2}-18,137$ (1.0), 130 (1.4), 127 (2.4), 126 (33) $\mathrm{BH}_{2}-\mathrm{CH}_{3} \mathrm{CHO}, 125$ (1.6) $\mathrm{BH}-\mathrm{CH}_{3} \mathrm{CHO}, 118(4.5), 117$ (91)S, 114 (3), 113 (50) $\mathrm{BH}_{2}-\mathrm{R}, 112$ (3), 111 (1.4), 110 (1.4), 108 (3), 100 (4), $99(50)$ S-18.

\section{RESULTS AND DISCUSSION}

\section{UV spectral results}

The UV peak maxima and absorbance ratios for fractions collected on the analytical HPLC system are listed in Table I. Peak maxima combined with absorbance ratios can be taken as the signature of most compounds and are powerful tools in identification of HPLC peaks $[8,9]$. Products with the same HPLC retention times had the same UV peak maxima and similar $254 / 280 \mathrm{~nm}$ absorbance ratios. The UV peak maximum for each site of dCyd alkylation is unique and therefore indicative of the position of alkylation [10]. Our results, similar to this review of the literature, show little variation in the peak maxima with a change in the attached alkyl group. All products eluting at $2 \mathrm{~min}$, labelled 1 , are consistent with $\mathrm{O}^{2}$ alkylation, those eluting at 4 min, labelled 3 , are consistent with $\mathrm{N}-3$ alkylation and the late eluting products, labelled 4 , are consistent with $\mathrm{N}^{4}$ alkylation. Unreacted dCyd, labelled 2 , eluted at $3 \mathrm{~min}$.

In addition to peak maxima and absorbance ratios, $\mathrm{O}^{2}$ and $\mathrm{N}-3$ alkylated dCyd products can be characterized by their differences in stability. It has been noted $[11,12]$ that $\mathrm{O}^{2}$-alkyl dCyd is less stable in alkali and acid than

\section{TABLE I}

HPLC RETENTION TIMES AND UV SPECTRA OF FRACTIONS IN FIG. 1.

\begin{tabular}{llll}
\hline Fraction & Peak maximum & $\begin{array}{l}\text { 254/280 nm } \\
\text { Absorbance ratio }\end{array}$ & $\begin{array}{l}\text { Retention } \\
\text { times (min) }\end{array}$ \\
\hline PO-1 & 263 & 2.29 & 2 \\
PO-2 & 277 & 0.40 & 3 \\
PO-3 & 282 & 0.31 & 4 \\
PO-4 & 294 & 0.26 & 6 \\
TCPO-1 & 263 & & 2 \\
TCPO-2 & 277 & 2.09 & 3 \\
TCPO-3 & 281 & 0.37 & 4 \\
& & 0.26 & 2 \\
EC-1 & 264 & & 3 \\
EC-2 & 276 & 1.94 & 4 \\
EC-3 & 281 & 0.40 & 5.5 \\
EC-4 & 293 & 0.35 & 2 \\
Gl-1 & 263 & 0.25 & 3 \\
Gl-2 & 278 & 2.28 & \\
\hline
\end{tabular}

${ }^{a}$ Taken in the HPLC buffer (pH 3.5). 


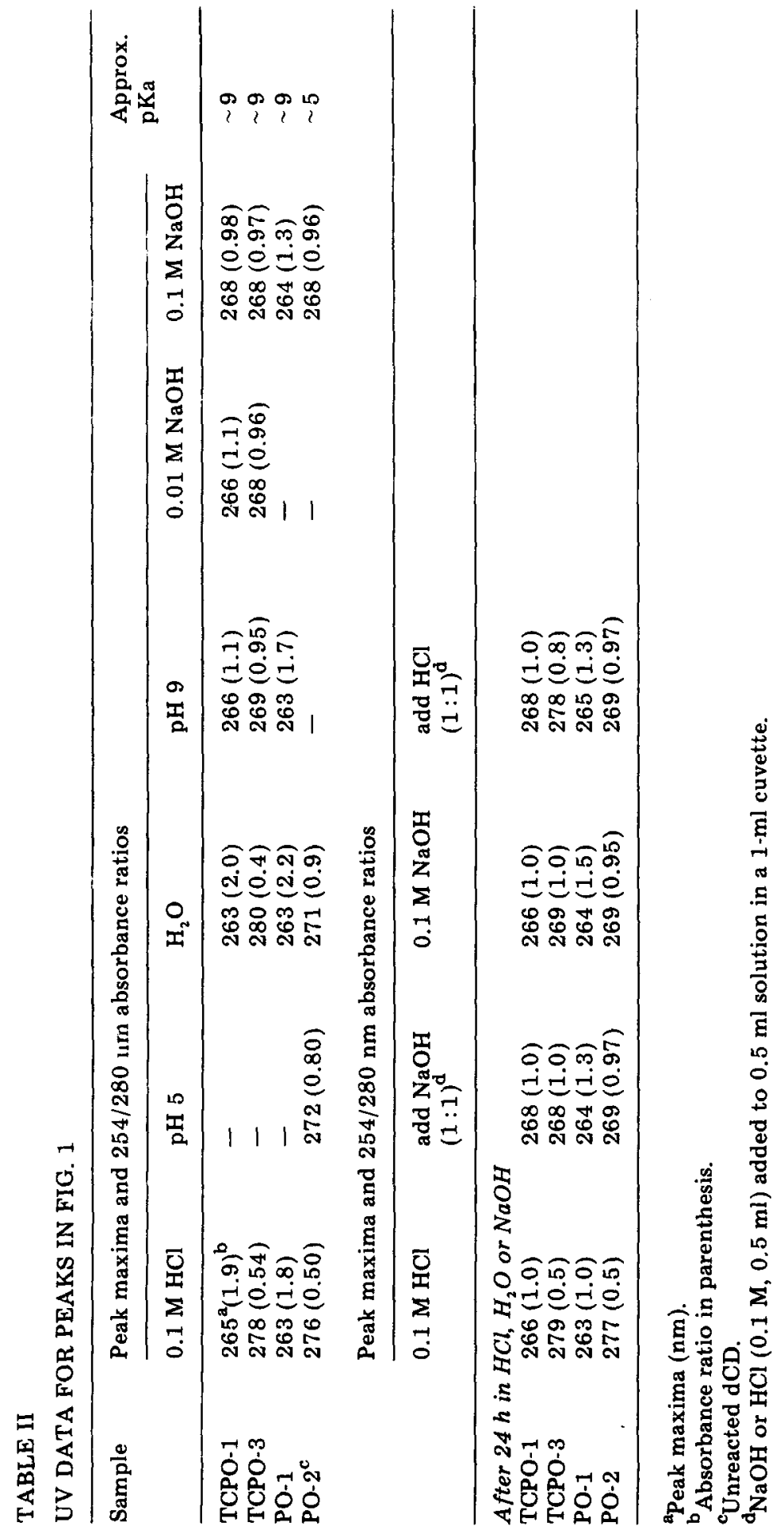


3-alkyl dCyd. The products isolated semi-preparatively, PO-1, TCPO-1 and TCPO-3, were subjected to acid and base treatment. It is apparent upon examination of Table II that both $0.1 \mathrm{M} \mathrm{HCl}$ and $0.1 \mathrm{M} \mathrm{NaOH}$ treatment irreversibly alters PO-1 and TCPO-1 while TCPO-3 and the unreacted PO-2 remains intact. This is consistent with identification of both PO-1 and TCPO-1 as $\mathrm{O}^{2}$-clkyl dCyd and TCPO-3 as 3-alky! dCyd. The spectra of PO-1, TCPO- 1 and TCPO-3 in $0.1 \mathrm{M} \mathrm{NaOH}$ and $0.1 \mathrm{M} \mathrm{HCl}$ are given in Fig. 2.

The measurement of UV peak maxima and absorbance ratios of PO-1, PO-2, TCPO-1 and TCPO-3 at several $\mathrm{pH}$ values, as indicated on Table II, allowed for an approximate determination of the pKa [13]. The $\mathrm{O}^{2}$ and $\mathrm{N}-3$ alkylated products, PO-1, TCPO-1 and TCPO-3 exhibit a pKa around 9 which is indicative of an imino structure $[11,14,15]$. The $\mathrm{N}^{4}$-alkylated products and unreacted dCyd, PO-2, which have the amino structure, exhibit a lower pKa around $4[10]$.

\section{$I R, N M R$ and $M S$ results}

To confirm the validity of product identification by UV peak maxima, additional spectral information was obtained for the major products from the least and most reactive epoxides, PO and TCPO. All the spectral information, as discussed below, supports the UV results that products with the same HPLC retention times are alkylated at the same site of dCyd. In the IR spectra the N-3 alkylated product, TCPO-3, is distinguished from the $\mathrm{O}^{2}$ alkylated products (TCPO-1 and PO-1) by the unique band at $1535 \mathrm{~cm}^{-1}$. This is similar to the band at $1556 \mathrm{~cm}^{-1}$ in the 3-methyl-dCyd spectrum. The products, PO-1, TCPO-1 and TCPO-3, have an absorbance band in the 1708$1726 \mathrm{~cm}^{-1}$ range which would be consistent with an imino structure $[16,17]$. This band is not present in the amino starting material. Both of the TCPO products show a strong $\mathrm{C}-\mathrm{Cl}$ absorption at $801 \mathrm{~cm}^{-1}$ [18].

The differences between $\mathrm{O}^{2}$ and $\mathrm{N}-3$ alkylation products are also evident in the $360 \mathrm{MHz}$ NMR spectra. Proton assignments in the spectra of unreacted dCyd (PO-2) and 3-methyl-dCyd were made according to existing literature [19-22] which was extended to the interpretation of the reaction products' spectra. Decoupling data was also used in the interpretation of the DMSO- $\mathrm{d}_{6}$ and $\mathrm{D}_{2} \mathrm{O}$ exchange spectra of the reaction products. The chemical shifts for the pyrimidine and alkyl adduct protons are listed in Table III. For both 3-methyl-dCyd and TCPO-3, the $6-\mathrm{H}$ is shifted to $7.4 \mathrm{ppm}$ from the usual $7.9 \mathrm{ppm}$ found in dCyd, PO-2, PO-1 and TCPO-1. In comparing the two TCPO alkylated products, the $\mathrm{CH}_{2}$ of TCPO-3 is found further upfield than the $\mathrm{CH}_{2}$ of TCPO-1, as would be expected for a $\mathrm{CH}_{2}$ on a nitrogen atom compared with a $\mathrm{CH}_{2}$ on an oxygen atom [23]. The alkyl adduct protons for both TCPO products are found further upfield than for the PO product due to the deshielding effect of the chlorines [24].

The mass spectra were useful in distinguishing between abnormal and normal product formation despite the fact that the products were marginally volatile for MS analysis, as is the case with dCyd [25]. Chemical ionization MS or derivitization with $N, O$-bis(trimethylsilyl)acetamide/trimethylchlorosilane/pyridine $(100: 1: 10)$ did not yield additional information over the 


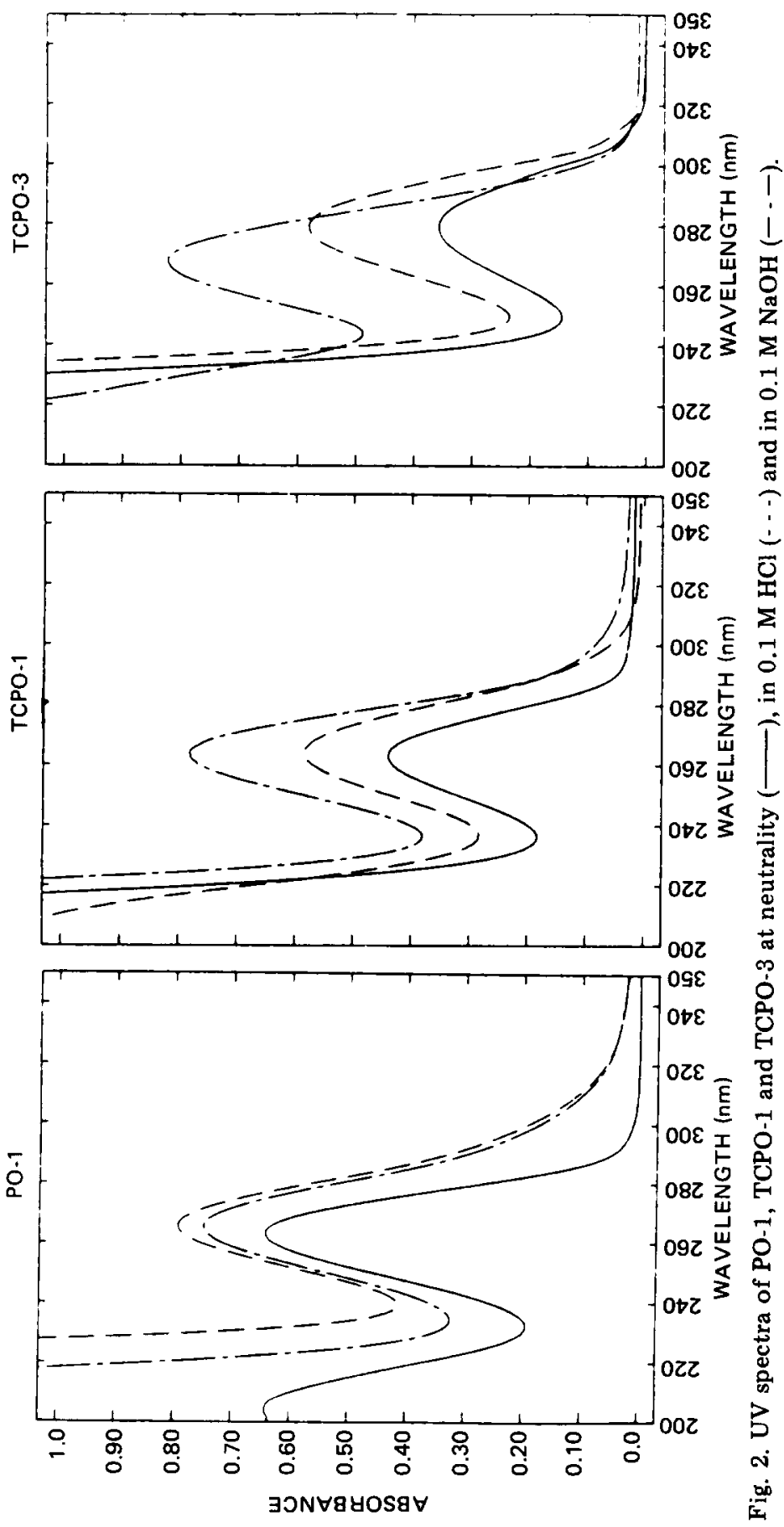




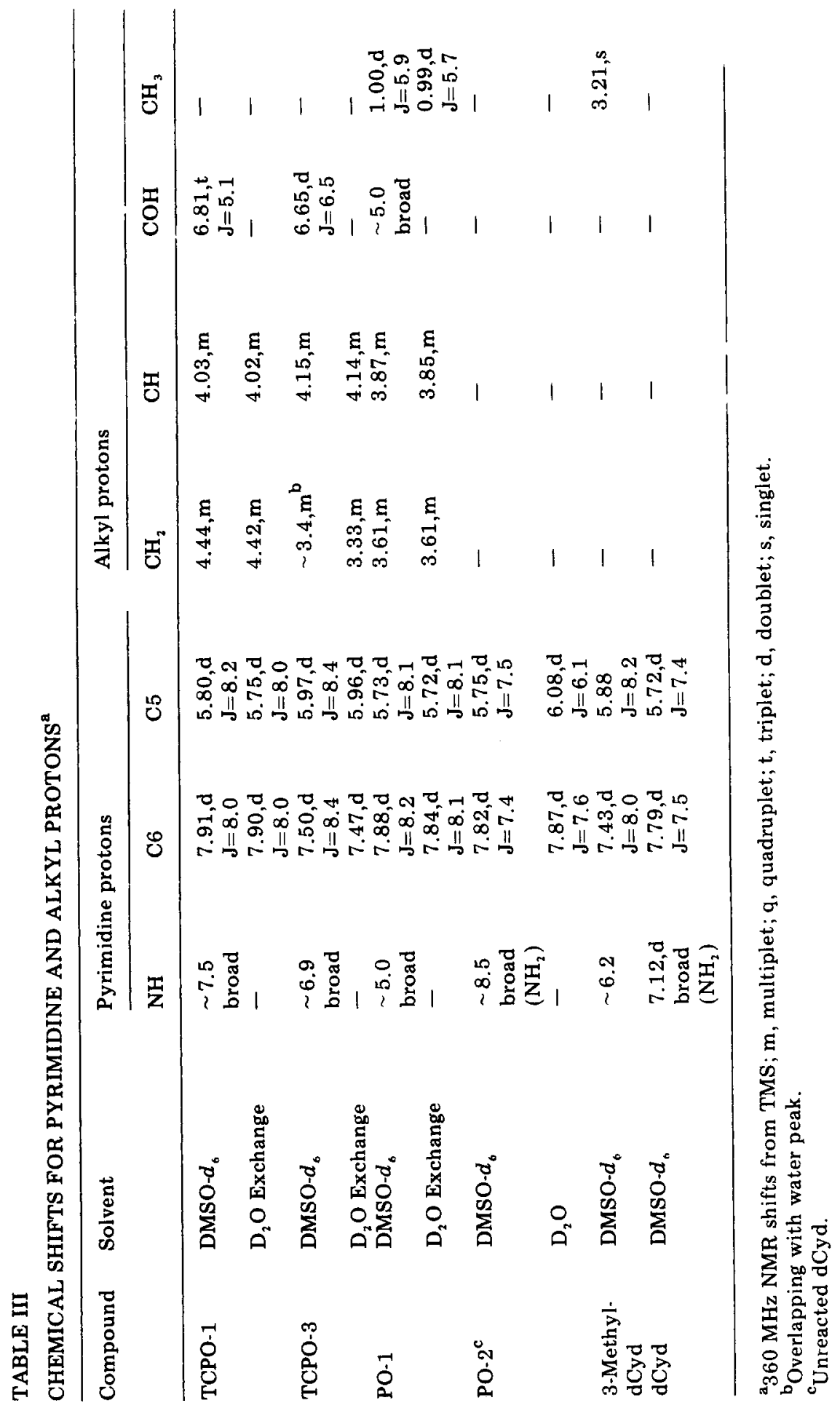


electron ionization spectra obtained and also were not satisfactory for the complete characterization of the dCyd derivatives. However, masses commonly found in nucleoside mass spectra from fragmentation of the molecular ion (M), pyrimidine base (B) and deoxysugar (S) moieties, such as $B+2$, $\mathrm{B}+28$ and $\mathrm{S}-18$ [25-27] are found in addition to masses expected for alkylated dCyd. Losses of alkyl side chain fragments from B are useful in distinguishing between normal (attachment at the least substituted carbon atom of the epoxide) and abnormal alkylation products. Similar to adenine alkylated by $\mathrm{PO}$ [3], normal alkylation allows for losses of $\mathrm{CH}_{3}, \mathrm{CCl}_{3}, \mathrm{CH}_{3} \mathrm{CHO}$ and $\mathrm{CCl}_{3} \mathrm{CHO}$ from the side chain while from the abnormal product losses of $\mathrm{CH}_{2} \mathrm{O}$ and $\mathrm{CH}_{2} \mathrm{OH}$ are expected. For the dCyd reaction products with $\mathrm{PO}$ and TCPO, the masses expected from normal product formation, $m / e 155$ and 125 , are present. No evidence was found for abnormal alkylation which would result in masses of $m / e 139$ and 140 for PO-1 and masses $m / e 240$ and 241 for the TCPO products.

\section{Comparative reactivity studies}

For dCyd reacted with PO, GL, EC and TCPO, the differences in product yields among the epoxides were evident on the analytical system (Fig. 1 and Table IV). In contrast with previous findings [6] of alkylation at the same site of DNA bases ( $\mathrm{N}-3$ for dCyd) by different epoxides, we report differences in reactivity towards sites on dCyd for the epoxides tested. As shown in Table IV, only the more reactive compounds, EC and TCPO, alkylate predominantly at the $\mathrm{N}-3$ position of dCyd. However, although differences in reactivity are present, it was total reactivity (represented by the ratio of remaining unreacted material, peak 2 , to internal standard) that correlated to Taft $\sigma$ *-electron withdrawing values [7] for the substituents.

TABLE IV

PEAK HEIGHT RATIOS AND TAFT $\sigma *$-VALUES

\begin{tabular}{|c|c|c|c|c|c|}
\hline \multirow[b]{2}{*}{ Reaction } & \multicolumn{4}{|c|}{ Peak height ratios ${ }^{a}$} & \multirow[b]{2}{*}{$\begin{array}{l}\text { Taft } \sigma^{*} \text { - } \\
\text { values }\end{array}$} \\
\hline & $1:$ IS $^{\mathbf{c}}$ & $2:$ IS & $3:$ IS & $4:$ IS & \\
\hline $\mathrm{dCyd} / \mathrm{PO}$ & $0.72 \pm 0.1$ & $2.9 \pm 0.3$ & $0.28 \pm 0.03$ & $0.09 \pm 0.06$ & 0.00 \\
\hline dCyd/GL & $2.0 \pm 0.06$ & $2.4 \pm 0.1$ & - & - & 0.56 \\
\hline dCyd/EC & $0.04 \pm 0.006$ & $2.0 \pm 0.06$ & $0.87 \pm 0.03$ & $0.17 \pm 0.006$ & 1.05 \\
\hline dCyd/TCPO & $0.70 \pm 0.1$ & $0.6 \pm 0.2$ & $1.2 \pm 0.4$ & - & 2.65 \\
\hline
\end{tabular}

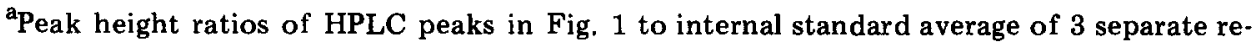
actions \pm S.D.

$b_{\text {Taft }}{ }^{*}$-values for substituents on the epoxides: $\mathrm{X}=\mathrm{CH}_{3}, \mathrm{HOCH}_{2}, \mathrm{ClCH}_{2}$ and $\mathrm{Cl}_{3} \mathrm{C}$ on $\mathrm{X}-\mathrm{CH}-\mathrm{CH}_{2}$ from Ref. 7 .

'Internal standard.
} 
The correlation of total reactivity to Taft $\sigma^{*}$-values was excellent $(r=0.9999)$ and is comparable to our previous correlation [28] with nicotinamide $(r=0.9438)$ and $p$-nitrobenzyl pyridine $(r=0.9474)$ reactivities. Deoxycytidine alkylation may be interesting to pursue in other alkylation studies since $O^{2}$-ethylcytosine has been found to persist in alkylated DNA in vivo $[29,30]$, and the more extensively studied formation and persistence of $O^{6}$-alkylguanine has not always correlated with toxicity [31-35]. In fact, for alkylated poly(deoxycytidylic-deoxyguanylic) acid, most misincorporations during replication have been found opposite modified cytosine residues [36].

\section{ACKNOWLEDGEMENTS}

This investigation was supported by Grant No. 1R01 CA 25770 awarded by the National Cancer Institute, DHHS.

\section{REFERENCES}

1 D.R. Wade, S.C. Airy and J.E. Sinsheimer, Mutagenicity of aliphatic epoxides, Mutat. Res., 58 (1978) 217.

2 S.H. Neau, B.H. Hooberman, S.W. Frantz and J.E. Sinsheimer, Substituent effects on the mutagenicity of phenyl glycidyl ethers in Salmonella typhimurium, Mutat. Res., 93 (1982) 297.

3 P. Lawley and M. Jarman, Alkylation by propylene oxide of deoxy ribonucleic acid, adenine, guanosine and deoxyguanylic acid, Biochem. J., 126 (1972) 893.

$4 \mathrm{~K}$. Hemminki, Fluorescence study of DNA alkylation by epoxides, Chem.-Biol. Interact., 28 (1979) 269.

5 K. Hemminki, K. Falck and H. Vainio, Comparison of alkylation rates and mutagenicity of directly acting industrial and laboratory chemicals, Arch. Toxicol., 46 (1980) 277.

6 K. Hemminki, J. Paasivirta, T. Kurkirinne and L. Virkki, Alkylation products of DNA bases by simple epoxides, Chem.-Biol. Interact., 30 (1980) 259.

7 R.W. Taft, Jr., Separation of polar steric and resonance effects in reactivity, in: $M$. Newman (Ed.), Steric Effects in Organic Chemistry, Wiley, New York, 1957, p. 619.

8 R. Yost, J. Stoveken and W. MacLean, Positive peak identification in liquid chromatography using absorbance ratioing with a variable-wavelength spectrophotometric detector, J. Chromatogr., 134 (1977) 73.

9 C.W. Gehrke, K.C. Kuo and R.W. Zumwalt, Chromatography of nucleosides, J. Chromatogr., 188 (1980) 129.

10 B. Singer, UV spectral characteristics and acidic dissociation constants of 280 alkyl bases, nucleosides and nucleotides, in: G.D. Fasman (Ed.), Handbook of Biochemistry and Molecular Biology, Nucleic Acids, Vol, I, 3rd edn., CRC Press, Cleveland, 1975 , p. 409.

11 B. Singer, $\mathrm{O}^{2}$-Alkyl cytidine - a new major product of neutral aqueous reaction of cytidine with carcinogens, FEBS Lett., 63 (1976) 85.

12 B. Singer, $M$. Kroger and $M$. Carrano, $\mathrm{O}^{2}$ - and $\mathrm{O}^{4}$-Alkyl pyrimidine nucleosides: stability of the glycosyl bond and of the alkyl group as a function of pH, Biochemistry, 17 (1978) 1246.

13 D. Shugar and J.J. Fox, Spectrophotometric studies of nucleic acid derivatives and related compounds as a function of pH. I. Pyrimidines, Biochim. Biophys. Acta, 9 (1952) 199. 
14 T. Ueda and J.J. Fox, Spectrophotometric studies of nucleic acid derivatives and related compounds. V. On the structure of 3-methylcytosine, J. Am. Chem. Soc., 85 (1963) 4024.

15 W.C. Johnson, Jr., P.M. Vipond and J.C. Grivod, Tautomerism in cytidine, Biopolymers, 10 (1971) 923.

16 D.M. Brown, M.J.E. Hewlins and P. Schell, The tautomeric state of N(4)-hydroxy and N(4)-amino-cytosine derivatives, J. Chem. Soc. (C), (1968) 1925.

17 H.T. Miles, Infrared spectra in tautomeric structure in $\mathrm{D}_{2} \mathrm{O}$ solution of some pyrimidine nucleosides and nucleotides, Biochim. Biophys. Acta, 22 (1956) 247.

18 D.H. Williams and I. Fleming, Spectroscopic Methods in Organic Chemistry, 3rd edn., McGraw-Hill, London, 1980, p. 65.

19 L. Gatlin and J.C. Davis, Jr., Comparison of ribose and deoxyribose nucleosides by n.m.r. and deductions regarding ribose and deoxyribose nucleic acids. I. Tautomeric form, J. Am. Chem. Soc., 84 (1962) 4464.

20 E.D. Becker, H.T. Miles and R.B. Bradley, Nuclear magnetic resonance studies of methyl derivatives of cytosine, J. Am. Chem. Soc., 87 (1965) 5575.

21 O. Jardetzky and G.C.K. Roberts, NMR in Molecular Biology, Academic Press, New York, 1981, p. 289.

22 Sadtler Research Laboratories, Inc., Nuclear Magnetic Resonance Spectra, Sadtler Research Laboratories, Inc., Philadelphia, 1978, $271171 \mathrm{M}$.

23 D.H. Williams and I. Fleming, Spectroscopic Methods in Organic Chemistry, 3rd edn., McGraw-Hill, London, 1980, p. 136.

24 R.M. Silverstein, G.C. Bassler and T.C. Morrill, Spectrometric Identification of Organic Compounds, 4th edn., John Wiley and Sons, New York, 1981, p. 225.

25 K. Bieman and J.A. McCloskey, Application of mass spectrometry to structure problems. VI. Nucleosides, J. Am. Chem. Soc., 84 (1962) 2005.

26 C. Hignite, Nucleic acids and derivatives, in: G.R. Waller (Ed.), Biochemical Applications of Mass Spectrometry, Wiley, New York, 1972, p. 437.

27 J.A. McCloskey, Mass spectrometry, in: P. Tso, (Ed.), Basic Principles of Nucleic Acid Chemistry, Academic Press, New York, 1974, p. 254.

28 H.J.F. Nelis, S.C. Airy and J.E. Sinsheimer, Comparison of the alkylation of nicotinamide and 4(p-nitrobenzyl) pyridine for the determination of aliphatic epoxides, Anal. Chem., 54 (1982) 213.

29 B. Singer, S. Spengler and W.J. Bodell, Tissue-dependent enzyme mediated repair or removal of O-ethyl pyrimidines and O-ethyl purines in carcinogen treated rats, Carcinogenesis, 2 (1981) 1069.

30 J.V. Frei, D.H. Swenson, W. Warren and P.D. Lawley, Alkylation of deoxyribonucleic acid in vivo and in various organs of C57BL mice by the carcinogens N-methyl-Nnitrosourea $\mathrm{N}$-ethyl-N-nitrosourea and ethyl methanesulphonate in relation to induction of thymic lymphoma, Biochem. J., 174 (1978) 1031.

31 G.P. Margison, H. Brésil, J.M. Margison and R. Montesano, Effect of chronic administration of dimethylnitrosamine on the excision of $\mathrm{O}^{6}$-methylguanine from rat liver DNA, Cancer Lett., 2 (1976) 79.

32 K.J. Rogers and A.E. Pegg, Formation of $\mathrm{O}^{6}$-methylguanine by alkylation of rat liver, colon and kidney DNA following administration of 1,2-dimethylhydrazine, Cancer Res., 37 (1977) 4082.

33 E. Scherer, A.P. Timmer and P. Emmelot, Formation of diethylnitrosamine and persistance of $\mathrm{O}^{4}$-ethylthymidine in rat liver DNA in vivo, Cancer Lett., 10 (1980) 1.

34 R. Montesano, H. Brésil, G. Planche-Martel, G.P. Margison and A.E. Pegg, Effect of chronic treatment of rats with dimethylnitrosamine on the removal of $\mathrm{O}^{6}$-methylguanine from DNA, Cancer Res., 40 (1980) 452.

35 J.W. Nicoll, P.F. Swann and A.E. Pegg, The accumulation of $\mathrm{O}^{6}$-methylguanine in the liver and kidney DNA of rats treated with dimethylnitrosamine for a short or a long period, Chem.-Biol. Interact., 16 (1977) 301.

36 J.A. Hall, R. Saffhill, T. Green and D.E. Hathaway, The induction of errors during in vitro DNA synthesis following chloroacetaldehyde treatment of poly(dA-dT) and poly (dC-dG) templates, Carcinogenesis, 2 (1981) 141. 